fluctuations will relate to the least productive slice of advertising expenditure on the reasonable assumption that advertising is subject to diminishing returns. Accordingly, an outright ban is likely to have far more effect than marginal changes. The report also considered survey evidence that nearly half of all smokers agree that "smoking cannot be really dangerous or the government would ban cigarette advertising."

The conclusion from the evidence amassed in the Department of Health's report is clearly that tobacco advertising affects the level of tobacco consumption. The government's white paper The Health of the Nation has set a target to reduce consumption of cigarettes by $40 \%$ and the prevalence of smoking to $20 \%$ by $2000 .{ }^{9}$ To this end the government has committed itself to maintaining the real value of cigarette excise duty. This is by no means sufficient to achieve these targets, ${ }^{10}$ which are necessarily ambitious, to cut morbidity and mortality from cancer, heart disease, and stroke.

Even with a considerable annual increase in real price and health education meeting these targets without an advertising ban is unlikely. The government has already banned tobacco advertising on television and accepts the need to control advertising. If control is good a ban must be better, and anything less would seem second best for health.

MRC Epidemiology and Medical Care Unit,

JOY TOWNSEND

Wolfson Institute of Preventive Medicine,

Medical College of St Bartholomew's Hospital,

London EC1M 6BQ

1 Department of Health Economics and Operational Research Division. Effect of tobacco advertising on tobacco consumption: a discussion document revieving the evidence. London: Department of Health, 1992

Warden J. Smoke screen over advertising bans. BM7 1992;305:1115.

3 New Zealand Department of Health. Health or tobacco: an end to tobacco advertising and promotion. Wellington: Toxic Substances Board, 1989

Pekurinen M. The demand for tobacco products in Finland. Br f Addiction 1989;84:1183-92.

5 Laugesen M, Meads C. Tobacco advertising restrictions, price, income, and tobacco consumption in OECD countries, 1960-1986. Br F Addiction 1991;86:1343-54.

6 Radfar M. The effect of advertising on total consumption of cigarettes in the UK. European Economic Review 1985;29:225-31.

McGuinness T, Cowling K. Advertising and the aggregate demand for cigarettes. European Economic Review 1975;6:311-28.

Marsh A, Matheson J. Smoking attitudes and behaviour. London: HMSO, 1983.

9 Secretary of State for Health. The health of the nation: a strategy for health in England. London: HMSO, 1992. (Cmnd 1986.)

10 Townsend J. Policies to halve smoking deaths. Addiction (in press).

\title{
Viral diarrhoeas in childhood
}

\section{Electron microscopy has improved our understanding}

Despite recent advances in oral rehydration therapy and improved diagnostic techniques an estimated five million preschool children die annually worldwide from the complications of acute, predominantly viral, diarrhoea. ${ }^{\prime}$ Mortality has plummeted in developed countries, though the number of admissions has not. ${ }^{2}$ This may be due to doctors frequently overestimating the severity of illness and dehydration ${ }^{2-4}$ and wrongly treating patients before admission. This happens in up to one third of children who see their general practitioners; many children receive unnecessary and potentially dangerous drugs. ${ }^{23}$ Fewer than one third receive an oral rehydration solution, ${ }^{2}$ and published guidelines on dietary management are often ignored. ${ }^{5}$

The first enteric virus, Norwalk agent, was identified in diarrhoeal stools by electron microscopy in 1972. ${ }^{6}$ The identification of rotavirus, ${ }^{7}$ enteric adenovirus, astrovirus, and calicivirus followed, and their pathogenicity was subsequently established. Rotaviruses are now recognised as the commonest cause of endemic acute diarrhoea in childhood, accounting annually for an estimated 140 million cases, one million deaths in young children, ${ }^{89}$ and most hospital admissions for diarrhoea in children under $2 .^{9}$ Attack rates are similar in developed and developing countries ${ }^{810}$; many infections are mild or asymptomatic.

Most infections in infants are due to group A rotaviruses, and at least seven serotypes of human rotavirus have been identified within this group. Groups B and C may also cause diarrhoea in humans. Vomiting may be severe, and fever is common. Watery diarrhoea persists for up to seven days and may be complicated by dehydration, acidosis, and transient carbohydrate intolerance.

With improved infant formulas and feeding practices hypernatraemia now occurs rarely in developed countries. Neonatal infection with the virus occurs but is often mild or asymptomatic, with maternal antibodies conferring protection. Recent evidence suggests that extraintestinal infection occurs in immunodeficient children. ${ }^{11}$ Rapid diagnosis can be made by electron microscopic detection of $70 \mathrm{~nm}$ wheel like particles in the stool. Commercial enzyme linked immunoassays for detecting group A rotavirus antigen in the stool are available. The use of the polymerase chain reaction as a research tool to detect rotavirus in stools may provide invaluable epidemiological information. ${ }^{8}$

Enteric adenoviruses serotypes 40 and 41 account for up to a sixth of cases of viral diarrhoea in children in Britain and the United States, ${ }^{910}$ ranking second to rotavirus. One in two children have neutralising antibodies by the age of $4 .{ }^{12}$ Diarrhoea is often protracted, but vomiting and fever are less prominent than with rotavirus. The $80 \mathrm{~nm}$ virus particles in the stool can be identified by electron microscopy, and typing is possible by various techniques.

Diarrhoea due to astrovirus is more common in young children than adults, in whom infection is rarely symptomatic. Symptoms are similar to those of infections with rotaviruses, but dehydration is uncommon. Serological evidence of past infection is present in nearly two thirds of British children by the age of 4 and in nearly $90 \%$ by the age of $10 .^{13}$

Electron microscopy of the stool shows a star shaped particle of 27-30 nm diameter. The recent development of an enzyme linked immunoassay using monoclonal antibodies has enabled the rapid detection of antigen common to all five serotypes in the stool and the clarification of the virus's role. In Thai children astrovirus accounted for $8.6 \%$ of cases of acute diarrhoea, being more common than enteric adenovirus. ${ }^{14}$ In contrast, detection rates were low in children presenting to hospital in the United States with diarrhoea and similar to rates in controls, ${ }^{15}$ and further controlled studies are needed to evaluate the virus's pathogenic role in developed countries.

Although more often implicated in adults, Norwalk virus also causes acute epidemic gastroenteritis in children. Vomiting is frequent, but diarrhoea and dehydration are mild. Serum antibody is not detected in children under 3 but is found in one fifth of children by 5 years of age and in more than three fifths of adolescents. ${ }^{16}$ Diagnosis of this small, round structured virus (27-35 $\mathrm{nm}$ diameter) can be made by electron microscopy or immunoassay. 
Norwalk is the prototype of a group of viruses associated with diarrhoea. While the pathogenicity of some of these Norwalk-like viruses is proved, that of others remains uncertain. Morphological and antigenic characteristics of the group suggest that they may belong to the calicivirus family, but confirmation awaits knowledge of their nucleic acid composition. At least five antigenically distinct strains of calicivirus cause an illness in humans similar to that caused by Norwalk virus. Some strains preferentially affect infants, and most 12 year olds have serological evidence of past infection. ${ }^{17}$

Coronoviruses, toroviruses (for example, Breda virus), parvoviruses, and the recently described picobirnaviruses have been associated with diarrhoea in humans, but their importance has not been established. ${ }^{910}$ Enteroviruses are commonly excreted in faeces but are not enteropathogenic. ${ }^{\circ}$ Cytomegalovirus, herpes simplex virus, and HIV may specifically infect the gastrointestinal tract and cause diarrhoea in the immunocompromised host.

\section{Treatment}

Oral rehydration therapy is the treatment of choice for viral diarrhoea with mild to moderate dehydration (that is, loss of up to $9 \%$ of body weight). Initial intravenous resuscitation will be needed in those with shock or severe dehydration. Suitable oral rehydration solutions for use in developed countries contain about 60 mmoles of sodium and 100 mmoles of glucose per litre and have low osmolalities to promote maximal absorption of water. ${ }^{1819}$

Several commercial solutions fit these specifications. They should be offered frequently to ensure sufficient volume for rehydration and replacement of ongoing losses and can be given nasogastrically. As rehydration solutions prevent as well as correct dehydration their early use should be encouraged.

Where malnutrition is common food based oral rehydration solutions ${ }^{20}$ are increasingly being used but they are not indicated on clinical or economic grounds in developed countries. Home remedies, including cordials and soft drinks which have low $\mathrm{pH}$ and high osmolality, may exacerbate diarrhoea and predispose to hypernatraemia; infant deaths have been associated with their use in dehydration.

Breast feeding should be continued during oral rehydration therapy and has been shown to decrease stool output. In older children, rapidly reintroducing starch based solids after rehydration is recommended. The widespread practice of slow reintroduction of milk feeds after oral rehydration therapy does not alter the incidence of intolerance to lactose or cows' milk protein.

Drugs, including antibiotics, antidiarrhoeals, and antiemetics, have no role in the management of viral diarrhoea.
Atropine-like drugs may cause respiratory depression and even death, and dystonic reactions to antiemetics are not uncommon in the dehydrated child.

Developing an oral vaccine against rotavirus is one of the World Health Organisation's priorities, but so far the results of clinical trials with several different vaccines have been conflicting and protection has been variable. The use of recombinant DNA techniques to express VP4 and VP7, the two main antigenic surface proteins on the outer capsid of

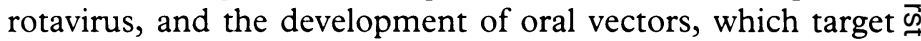
the gastrointestinal tract, are further advances towards an effective vaccine that will undoubtedly be our most important $\frac{\bar{F}}{\bar{N}}$ weapon against viral diarrhoea in future..$^{9}{ }^{21}$ In the meantime, educating parents and health professionals in the optimal $\stackrel{\mathbb{\perp}}{\circ}$ management of viral diarrhoea will further reduce morbidity क and minimise the need for admission to hospital and admini- $\vec{o}$ stration of intravenous fluids.

ELIZABETH J ELLIOTT

Senior Lecturer in Paediatrics and Child Health,

University of Sydney,

Royal Alexandra Hospital for Children,

Camperdown,

NSW 2050,

Australia

Rhode JE. Selective primary health care: strategies for control of disease in the developing world XV. Acute diarrhoea. Rev Infect Dis 1984;6:840-54.

Conway SP, Phillips RR, Panday S. Admission to hospital with gastroenteritis. Arch Dis Child 1990;65:579-84.

3 Jenkins HR, Ansari BM. Management of gastroenteritis. Arch Dis child 1990;65:939-41.

4 Mackenzie A, Barnes G, Shann F. Clinical signs of dehydration in children. Lancet 1989;ii:605-7. 5 Wharton BA, Pugh RE, Taitz LS, Walker-Smith JA, Booth IW. Dietary management of gastroenteritis in Britain. BMF 1988;296:450-2

6 Kapikan AZ, Wyatt RG, Dolin R. Visualization by immune electron microscopy of a $27 \mathrm{~nm}$ particle associated with acute infectious nonbacterial gastroenteritis. F Virol 1972;10:1075-80. 7 Bishop RF, Davidson GP, Holmes IH, Ruck BJ. Virus particles in epithelial cells of duodenal mucosa from children with acute non-bacterial gastroenteritis. Lancet 1973;ii:1281-3.

8 Wilde J, Yolken R, Willoughby R, Eiden J. Improved detection of rotavirus shedding by polymerase chain reaction. Lancet 1991;337:323-6.

9 Blacklow NR, Greenberg HB. Viral gastroenteritis. N Engl f Med 1991;325:252-64.

10 Barnes GL. Intestinal viral infections. In: Walker WA, Durie PR, Hamilton JR, Walker-Smith JA, Watkins JB. eds. Pediatric gastrointestinal disease. Philadelphia: B C Decker, 1991:538-46.

11 Gilder MA, Matson DO, Connerr ME, Rosenblatt HM, Finegold MJ, Estes MK. Extraintestinal rotavirus infections in children with immunodeficiency. I Pediatr 1992;120:912-7.

12 Wadell G, Allard A, Svensson L, Uhnoo I. Enteric adenoviruses. In: Farthing MJC, ed. Viruses and the gut. Oxford: Herb Bowes Graphics, 1989:70-8.

13 Kurtz JB, Lee TW, Craig JW, Reed SE. Astrovirus infection in volunteers. $f$ Med Virol $\vec{F}$ 1979;3:221-30

14 Herrman JE, Taylor DN, Echeverria P, Blacklow NR. Astroviruses as a cause of gastroenteritis in children. N Engl F Med 1991;324:1757-60.

15 Kotloff KL, Herrman JE, Blacklow NR, Hudson RW, Wasserman SS, Morris JG, et al. The frequency of astrovirus as a cause of diarrhoea in Baltimore children. Pediatr Infect Dis $\mathcal{Y}$ 1992;11:587-9.

16 Kapikian AZ, Greenberg HB, Wyatt RG, Kalica AR, Chanock RM. The Norwalk group of viruses-agents associated with epidemic viral gastroenteritis. In: Tyrell DAJ, Kapikian AZ, eds. Virus infections of the gastrointestinal tract. New York: Marcel Dekker, 1982;147-77.

17 Cubitt WD. Caliciviruses. In: Farthing MJG, ed. Viruses and the gut. Oxford: Herb Bowes Graphics, 1989:82-7.

18 ESPGAN Working group. Recommendations for composition of oral rehydration solutions for the children of Europe. 7 Pediatr Gastroenterol Nutr 1992;14:113-5.

19 Elliott EJ, Cunha-Ferreira RC, Walker-Smith JA, Farthing MJG. Sodium content of oral renter

20 Gore $\mathrm{S}$, Fontaine $\mathrm{O}$, Pierce $\mathrm{N}$. Impact of rice-based oral rehydration solution of stool output and duration of diarrhoea: meta-analysis of 13 clinical trials. BM7 1992;304:287-91.

21 Flores J, Perez-Schael I, Zapikian AZ. Approaches to rotavirus vaccination. In: Farthing MJG, ed. Viruses and the gut. Oxford: Herb Bowes Graphics, 1989:109-19. 